\title{
The Condition of the Sanitary Infrastructure in the Bialski District in Poland and the Need for its Development
}

\author{
Karolina Jóźwiakowska1", Michał Marzec ${ }^{2}$ \\ 1 Student, Faculty of Civil and Environmental Engineering, Warsaw University of Life Sciences, Nowoursynowska \\ 159, 02-787 Warsaw, Poland \\ 2 Department of Environmental Engineering and Geodesy, University of Life Sciences in Lublin, Leszczyńskiego 7, \\ 20-069 Lublin, Poland \\ * Corresponding author's e-mail: karolina.jozwiakowska@tlen.pl
}

\begin{abstract}
The aim of this paper was to present the current state and the need for development of the sanitary infrastructure in the communes of the Bialski District located in the Lublin Voivodeship. The Bialski District encompasses 2 urban communes: Miedzyrzec Podlaski and Terespol and 17 rural communes: Biała Podlaska, Drelów, Janów Podlaski, Kodeń, Konstantynów, Leśna Podlaska, Łomazy, Międzyrzec Podlaski, Piszcząc, Rokitno, Rossosz, Sławatycze, Sosnówka, Terespol, Tuczna, Wisznice and Zalesie. The present paper uses the data from the surveys conducted in these communes in 2016. On average, $79.2 \%$ of the population used the water supply system in the surveyed communes, while $39.4 \%$ of the inhabitants had the possibility of discharging wastewater to the sewerage system. In the area of the communes, there were 20 collective, mechanical and biological wastewater treatment plants with a capacity exceeding $5 \mathrm{~m}^{3} / \mathrm{d}$. The households which were not connected to the wastewater network, discharged wastewater mainly to non-return tanks. In the surveyed communes, there were 4437 household wastewater treatment plants. Most of them (above 80\%) were the systems with infiltration drainage, which do not ensure high efficiency of pollutants removal and may even contribute to the degradation of the groundwater quality. In order to solve the existing problems of wastewater and water management occurring in the communes where the Bialski District is located, it is necessary to further develop collective wastewater systems and equip the areas characterized by dispersed housing with highly efficient household treatment plants, e.g. constructed wetlands.
\end{abstract}

Keywords: district, septic tanks, household wastewater treatment plants, collective wastewater treatment plants, water supply network, sewerage systems

\section{INTRODUCTION}

Water is one of the most important resources on Earth. It determines both the human health and the standard of living of the population. During the last 20 years, the volume of water intake in particular sectors of the Polish economy has not changed significantly: $70 \%$ of water has been used by the industry, $20 \%$ by municipal management, $10 \%$ for irrigation in agriculture and forestry and filling and replenishing fish ponds [CSO 2019]. For the industrial purposes, mainly surface water has been used. Groundwater, which is characterized by much better quality than surface water, has been used mainly as a source of drinking water for the population.
The social and economic transformations in Poland, the increase in the ecological awareness and greater care for the state of the environment, as well as greater availability of new technological solutions contributed to an increase in the length of both the water supply network and the sewerage system in recent years [CSO 2019].

The aim of the study was to present the current state of the sanitary infrastructure in the communes of the Bialski District, which is part of the Lublin Voivodeship. The results of a survey conducted in 2016 by the Department of Environmental Engineering and Geodesy of the University of Life Sciences in Lublin and the data from the Statistical Office in Lublin [CSO 2017] were used in the paper. The method employed in the 
research was a diagnostic survey and the research technique was a questionnaire. The questionnaire was sent to the offices of 19 communes located in the Bialski District. Feedback was received from 17 communes, whereas some of them did not contain all the answers. When no feedback was available from some communes, if possible, the data from the CSO was used [2016].

The research, involved a questionnaire consisting of 10 closed questions concerning the water and wastewater infrastructure existing in each given commune. The questions included in the questionnaire concerned: the length of the water supply network and sewerage system, the number of people using the water supply and sewerage system, as well as the number and types of collective and domestic wastewater treatment plants. The information concerning the number of functioning non-effluent tanks (septic tanks) and the needs of the commune in terms of water and sewerage infrastructure development was collected as well. The obtained information was analysed and the results were presented in a tabular and graphical form.

\section{CHARACTERISTICS OF THE RESEARCH AREA}

The Bialski District is located in the northeastern part of the Lublin Voivodeship. It is the largest district of the voivodeship. Its area is about $2755 \mathrm{~km}^{2}$, which is about $11 \%$ of the voivodeship area (Fig. 1). In 2016, 112.5 thousand people lived here, and the average population density was 40 people $/ \mathrm{km}^{2}$ [Statistical Office in Lublin 2019].

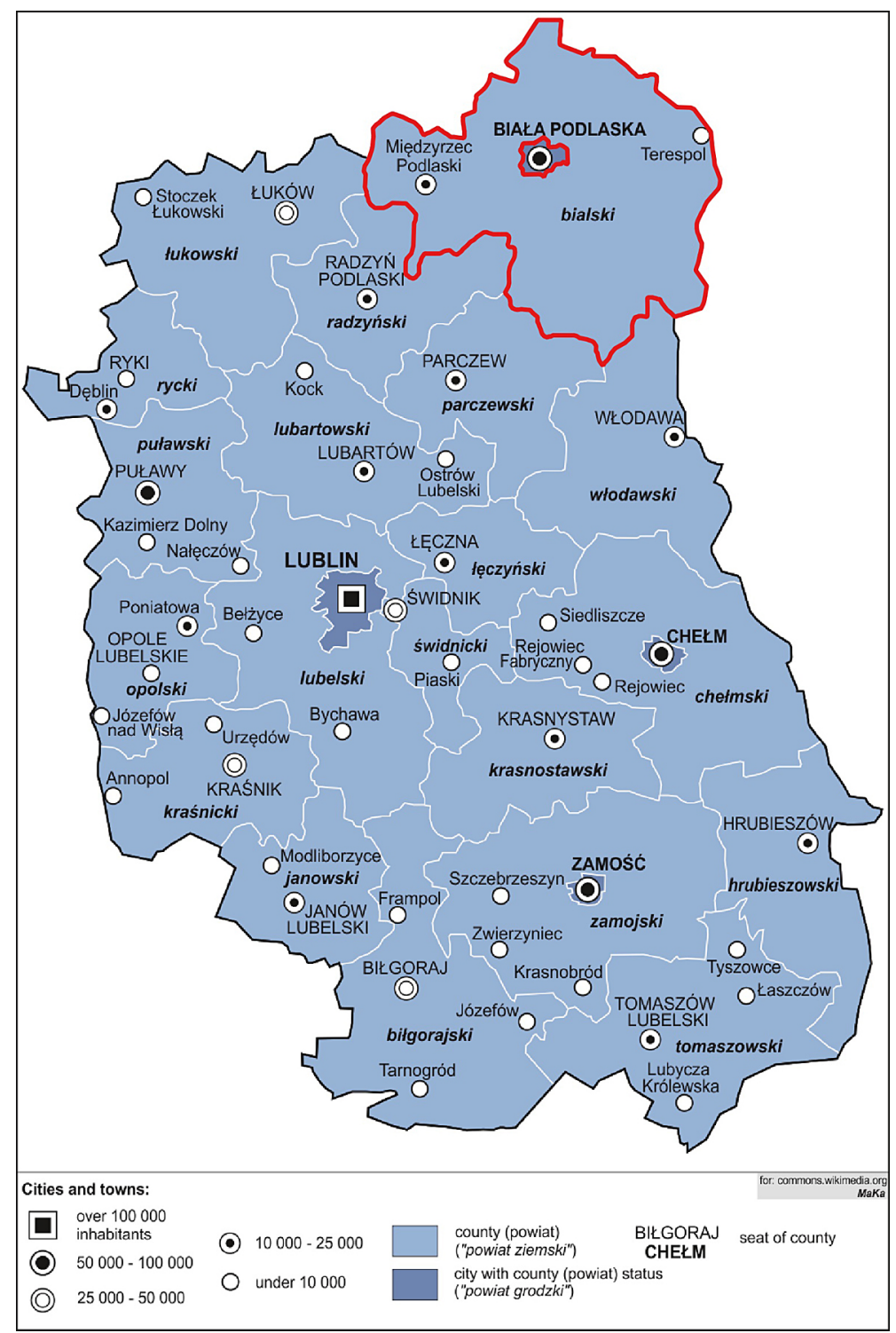

Fig. 1. Location of the Bialski District in the Lublin Voivodeship [http1] 
The eastern and northern border of the district is marked by the largest river in the region - the Bug River. It is also the border between Poland and Belarus.

The Bialski District consists of 2 urban communes: Miedzyrzec Podlaski and Terespol and 17 rural communes: Biała Podlaska, Drelów, Janów Podlaski, Kodeń, Konstantynów, Leśna Podlaska, Łomazy, Międzyrzec Podlaski, Piszcząc, Rokitno, Rossosz, Sławatycze, Sosnówka, Terespol, Tuczna, Wisznice and Zalesie (Fig. 2). The administrative seat of the Bialski District is the city of Biala Podlaska, which is a separate unit - a city with district rights.

The largest commune of the district - Biała Podlaska has an area of $325 \mathrm{~km}^{2}$ (about $12 \%$ of the district area), while the smallest is the urban commune of Terespol with an area of $10 \mathrm{~km}^{2}$, which is $0.4 \%$ of the district area (Table 1 ).

The District Office in Biała Podlaska [2020] states that about $20 \%$ of the district population live in towns and $80 \%$ live in rural areas. The most populated communes (outside the cities) are among others: Terespol, Konstantynów, Leśna Podlaska and Piszczac, the least people live in the following communes: Rossosz, Sławatycze and Sosnówka.
The Bialski District is characterized by a negative natural growth, increasing in recent years, and a negative balance of migration [The District Office in Biala Podlaska 2020]. There are 340 villages in the district, with agriculture as the main economic activity. In the total area of the district, the agricultural land occupies $67.1 \%$, forests and forest land $28.3 \%$ while the remaining land and wasteland $4.5 \%$. The main crops cultivated in the district are cereals, potatoes, vegetables and fruits. The livestock production is dominated by cattle and pig farming. Due to the agricultural character of the area and the lack of industrial plants polluting the environment, the individual farms located here produce healthy, high-quality food. Therefore, the agri-food processing and light, wood and metal industries, as well as the production of building materials develop well in the district. The border location on the axis of important transcontinental transport routes has contributed to the development of transport companies. Horse breeding in the stud farm in Janów Podlaski is also of particular importance. There is the Podlasie Bug River Gorge Landscape Park, 8 nature reserves and 282 monuments of living and inanimate nature [The District Office in Biala Podlaska 2020].

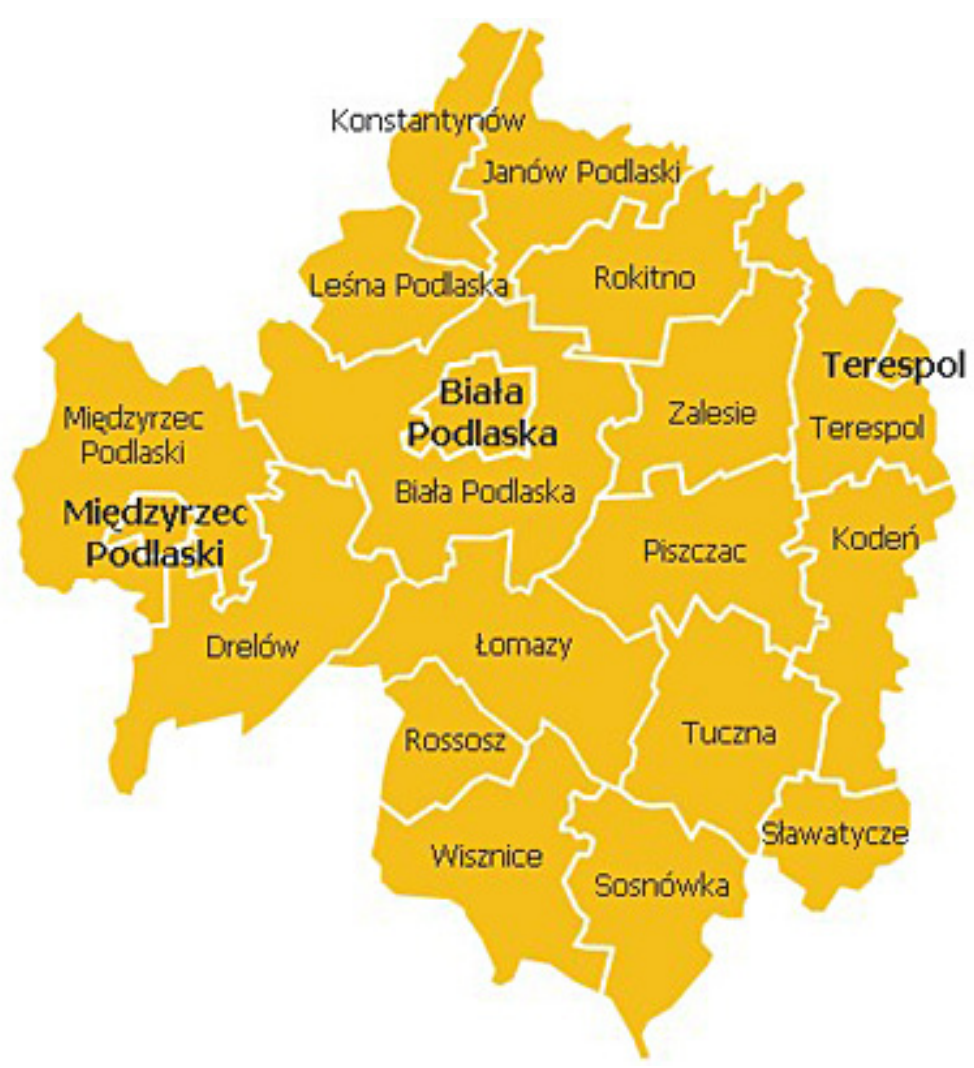

Fig. 2. The communes in the Bialski District [http2] 
Table 1. Characteristics of the communes in the Bialski District [own research and CSO 2016]

\begin{tabular}{|l|c|c|c|c|}
\hline \multicolumn{1}{|c|}{ Name of the commune } & Area $\left[\mathrm{km}^{2}\right]$ & $\begin{array}{c}\text { Population } \\
\text { [people] }\end{array}$ & $\begin{array}{c}\text { Population density } \\
\text { [people/km²] }\end{array}$ & $\begin{array}{c}\text { Share of the commune area in } \\
\text { relation to the district [\%] }\end{array}$ \\
\hline Biała Podlaska & 325 & 14000 & 43 & 11.8 \\
\hline Drelów & 228 & 5593 & 25 & 8.3 \\
\hline Janów Podlaski & 136 & 5408 & 40 & 5.9 \\
\hline Kodeń & 151 & 3756 & 25 & 3.2 \\
\hline Konstantynów & 87 & 4247 & 49 & 3.6 \\
\hline Leśna Podlaska & 98 & 4363 & 45 & 7.2 \\
\hline Łomazy & 199 & 5228 & 26 & 9.5 \\
\hline Międzyrzec Podlaski & 262 & 10531 & 40 & 0.8 \\
\hline Międzyrzec Podlaski (urban) & 21 & 17301 & 824 & 6.2 \\
\hline Piszcząc & 170 & 7504 & 44 & 5.1 \\
\hline Rokitno & 141 & 3142 & 22 & 2.8 \\
\hline Rossosz & 76 & 2331 & 31 & 2.6 \\
\hline Sławatycze & 72 & 2372 & 35 & 5.4 \\
\hline Sosnówka & 148 & 2600 & 18 & 5.1 \\
\hline Terespol & 141 & 6743 & 48 & 0.4 \\
\hline Terespol (urban) & 10 & 5830 & 583 & 6.2 \\
\hline Tuczna & 170 & 3309 & 19 & \\
\hline Wisznice & 173 & 5130 & 30 & \\
\hline Zalesie & 147 & 4535 & 31 & 5.3 \\
\hline
\end{tabular}

\section{RESULTS AND DISCUSSION}

A characteristic feature of the Polish water and wastewater management is the noticeable, but too slow, development of the sewerage system (Table 2). The persisting difference between the length of the water supply network and the sewerage system is even more visible when comparing cities with rural areas.

According to the data of the Statistical Office in Lublin [2017], the total length of the water supply network in all the communes of Bialski District in 2016 was over $1950 \mathrm{~km}$ (Table 3), which constituted about $9.2 \%$ of the length of the water supply network of the entire Lublin Voivodeship. However, it was not distributed evenly [Statistical Office in Lublin 2017].

The longest water supply network was $197 \mathrm{~km}$ in the Biała Podlaska Commune. The shortest water supply network was in the Rossosz Commune - $17.5 \mathrm{~km}$. However, the length of the water supply network should not be a determinant for the evaluation of the drinking water supply for the population, because it depends on many factors, such as: the size of the commune, the settlement method which is dominant in a given area and the housing density. Such a large disproportion between the length of the water supply network proves a very spatially diverse settlement network. The commune with the longest water supply network is at the same time the largest commune of the Bialski District.

Among the analyzed communes, the highest level of water supply was in the Międzyrzec Podlaski commune $-99.2 \%$ of the population used the water supply network (Fig. 3). It is characterized by the second longest water supply network in the district - $179.3 \mathrm{~km}$ and one of the largest areas $-262 \mathrm{~km}^{2}$. The lowest percentage of the population using the water supply system was in the Łomazy Commune - $24 \%$ of population. With quite a large area of this commune $199 \mathrm{~km}^{2}$, in 2016 it was inhabited by half of the population of the Międzyrzec Commune, while the length of the water supply network amounted to $153.61 \mathrm{~km}$ and was one of the greatest in the district. Such data prove dispersed population in centres of the commune.

Table 2. Length of the water supply network and the sewerage system (in thousand $\mathrm{km}$ ) in Poland in 2000-2018 [CSO 2019]

\begin{tabular}{|l|c|c|c|c|c|c|}
\hline \multicolumn{1}{|c|}{ Length of the } & 2000 & 2005 & 2010 & 2015 & 2017 & 2018 \\
\hline Water supply network & 211.9 & 245.6 & 272.9 & 297.9 & 303.9 & 307.7 \\
\hline Sewerage system & 51.1 & 80.1 & 107.5 & 149.7 & 156.9 & 160.7 \\
\hline
\end{tabular}




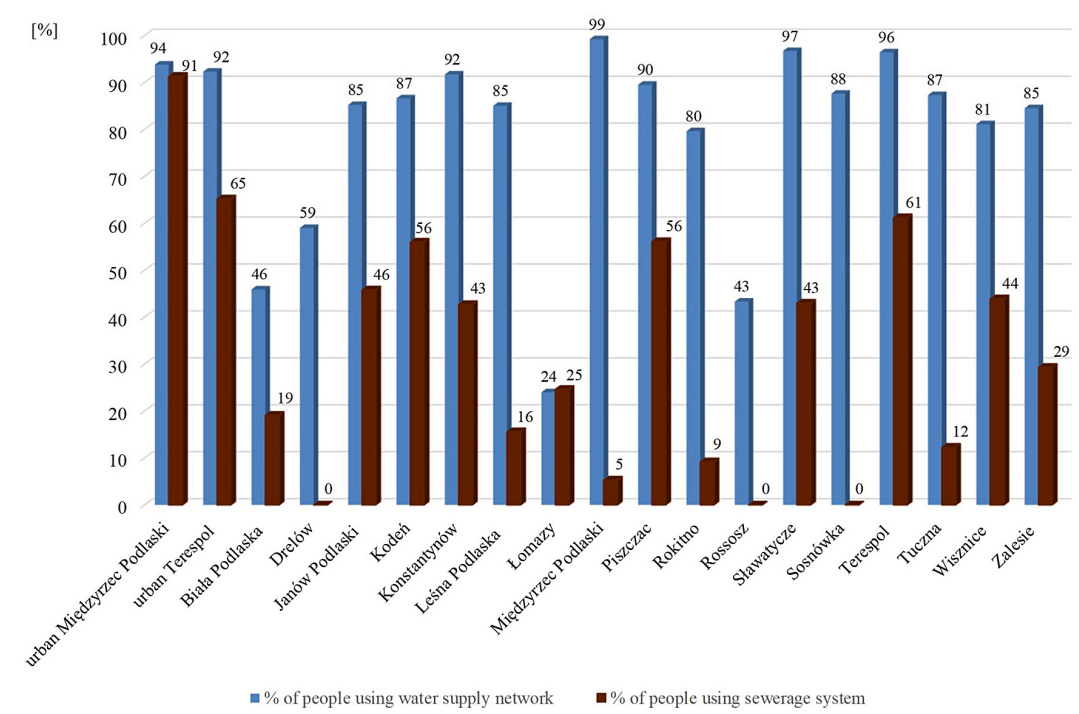

Fig. 3. The level of the water supply network and the sewerage system in the communes of Bialski District in 2016

The Surveys carried out in the neighbouring districts show that in Radzyn District, the total length of the water supply network in 2016 was over $880 \mathrm{~km}$ and was used by $90 \%$ of the district population [Bogusz et al. 2020]. In turn, in the Parczew District, the total length of water supply system was $630 \mathrm{~km}$ and on average was used by $88 \%$ of the population of the district [Micek et al. 2018]. Despite the fact that in 2016 the water supply network on the territory of Bialski District was used on average by about $79.2 \%$ of the population, the analysis of the collected survey data allows us to assess the condition of the water supply infrastructure in the discussed district as unsatisfactory.

On the basis of the analysis of the data from the survey on the length of the sewerage network in each commune of the Bialski District, it was found that in 2016, it did not exist in the communes of Drelów and Rossosz, whereas in the commune of Sosnówka the sewerage system was still under construction, and in the remaining 16 communes it was already partly in operation. The total length of the sewerage system in the Bialski District in 2016 was $497.5 \mathrm{~km}$, which constituted $7.7 \%$ of the length of the wastewater network of the entire Lublin Voivodeship [Statistical Office in Lublin 2017]. The longest sewerage network - $98.8 \mathrm{~km}$ was found in the commune of Piszczac. Its length constituted almost $20 \%$ of the length of the network in the whole district. The results of the survey showed that the number of people using the sewerage system varied greatly and ranged from 15806 people in the urban commune of Międzyrzec Podlaski to 406 people in the Tuczna Commune.
In order to be able to compare individual communes, the average length of the network per each inhabitant using the sewerage system was calculated. According to the National Municipal Wastewater Treatment Programme [KPOŚK 2017], the unit length of the sewerage network should not exceed about $8 \mathrm{~m}$ per capita [Heidrich, Stańko 2008; AKPOŚK 2017]. In the case of the Bialski District communes, only three meet these requirements: the urban commune of Międzyrzec Podlaski - 3.9 m/M, Łomazy $-6.6 \mathrm{~m} / \mathrm{M}$ and Rokitno - $3.5 \mathrm{~m} / \mathrm{M}$. However, in the case of the latter, it should be noted that this is the shortest existing sewerage network in the district with a length of $1 \mathrm{~km}$. In three other communes, a unitary length of the sewerage network was slightly exceeded, as it was 8.0 in the commune of Kodeń, 8.4 - Konstantynów and 8.7 in Janów Podlaski Commune. The other communes were characterized by a unitary length of the sewerage network which was many times greater than the advised value, i.e: from 9.06 in the commune of Terespol to 39.8 in the Tuczna Commune.

After analyzing the level of the sewerage system in the communes of Bialski District, it was noticed that it was high only in the urban commune of Międzyrzec Podlaski and amounted to $91.3 \%$. In the remaining communes, it ranged from $65.2 \%$ in the urban Terespol Commune and $61.2 \%$ in the Terespol Commune to $5.3 \%$ in the Międzyrzec Podlaski Commune. It should be noted that in 5 communes (Biała Podlaska, Leśna Podlaska, Międzyrzec Podlaski, Rokitno and Tuczna) it did not even reach $20 \%$ (Fig. 3). 
Table 3. Length of the water supply network and the sewerage system and the number of water supply and the wastewater system users in Bialski District in 2016

\begin{tabular}{|c|c|c|c|c|c|}
\hline Commune & $\begin{array}{c}\text { Population } \\
\text { [people] }\end{array}$ & $\begin{array}{c}\text { Length of the } \\
\text { water supply } \\
\text { network [km] }\end{array}$ & $\begin{array}{c}\text { Users of the water } \\
\text { supply network } \\
\text { [people] }\end{array}$ & $\begin{array}{c}\text { Length of the } \\
\text { sewerage system } \\
{[\mathrm{km}]}\end{array}$ & $\begin{array}{c}\text { Users of the } \\
\text { sewerage system } \\
\text { [people] }\end{array}$ \\
\hline $\begin{array}{c}\text { Urban Międzyrzec } \\
\text { Podlaski }\end{array}$ & 17301 & 59.0 & 16228 & 62.3 & 15806 \\
\hline Urban Terespol $^{*}$ & 5830 & 28.4 & 5381 & 34.5 & 3804 \\
\hline Biała Podlaska & 14000 & 197.0 & 6432 & 33.0 & 2670 \\
\hline Drelów & 5593 & 109.7 & 3300 & 0.0 & 0 \\
\hline Janów Podlaski & 5408 & 94.3 & 4608 & 21.5 & 2480 \\
\hline Kodeń & 3756 & 89.9 & 3252 & 16.8 & 2100 \\
\hline Konstantynów & 4247 & 88.5 & 3893 & 15.2 & 1815 \\
\hline Leśna Podlaska & 4363 & 115.7 & 3710 & 8.2 & 682 \\
\hline Łomazy & 5228 & 153.6 & 1257 & 8.5 & 1286 \\
\hline Międzyrzec Podlaski & 10531 & 179.3 & 10444 & 10.5 & 557 \\
\hline Piszczac & 7504 & 146.4 & 6715 & 98.8 & 4211 \\
\hline Rokitno & 3142 & 88.8 & 2500 & 1.0 & 289 \\
\hline Rossosz & 2331 & 17.5 & 1010 & 0 & 0 \\
\hline Sławatycze & 2372 & 66.5 & 2294 & 22.6 & 1019 \\
\hline Sosnówka & 2600 & 73.2 & 2251 & - & - \\
\hline Terespol & 6743 & 124.2 & 5947 & 55.1 & 4124 \\
\hline Tuczna & 3309 & 104.6 & 2888 & 16.2 & 406 \\
\hline Wisznice & 5130 & 134.3 & 4159 & 57.8 & 2251 \\
\hline Zalesie & 4535 & 79.3 & 3831 & 35.5 & 1331 \\
\hline TOTAL & 113923 & 1891.2 & 90100 & 497.5 & 44831 \\
\hline
\end{tabular}

* CSO 2016

The conducted research allowed determining that in the Bialski District 39.4\% of its inhabitants used the sewerage system, on average, while in the neighbouring districts: Radzyń $-35 \%$ of the population [Bogusz et al. 2020] and in Parczew - 48\% [Micek et al. 2018].

A characteristic feature of the water and wastewater management in the Lublin Voivodeship is that the development of the sewerage system does not keep up with the needs. This is due to the fact that the development of the sewerage network is strictly conditioned by the accessibility of the population to water supply, and its construction is more difficult and expensive.

From the data of the Local Government Portal [2017] concerning the water supply and wastewater system management in Poland it can be observed that in 2017 , on the scale of the whole country, about $84 \%$ of the country's population used a water supply network, while only about $53 \%$ used a sewerage system. By analyzing the urban-rural relationship, it can be seen that less than a quarter of people used a sewerage system in rural areas, compared to cities [Local Government Portal 2017].
In the Bialski District, a clear difference is also observed in the access of the population to the water supply system $-79.2 \%$ and to the sewerage system $-39.4 \%$. Poorer communes often do not have sufficient funds for independent development of sewerage infrastructure or for obtaining appropriate support [Statistical Office in Lublin 2017].

In rural communes, mainly in the areas with dispersed housing, the diversity in an access to the infrastructure is very high. While the level of water supply network is quite high, the construction of the sewerage system is economically unprofitable. The greatest disparities were found in the commune of Międzyrzec Podlaski, where the level of water supply was $99.2 \%$ but the level of sewerage system was 5.3\%. A similar situation was observed in the communes where there was a water supply network, but no sewerage system: Drelów, Rossosz, Sosnówka and Rokitno. In urban communes, the difference between the percentage of the population using the water supply and the sewerage system was smaller (Fig. 3).

In rural areas, where buildings are not sufficiently concentrated, there no sewerage system was built. Municipal wastewater is collected in 
septic tanks and transferred to collective wastewater treatment plants. In 2016, there were 20 collective mechanical-biological wastewater treatment plants with a capacity of $5 \mathrm{~m}^{3} / \mathrm{d}$ on the territory of the Bialski District communes. The urban commune of Międzyrzec Podlaski had a treatment plant with the largest capacity $-2000 \mathrm{~m}^{3} / \mathrm{d}$. This was due to its urban character - it served a very large population. On the other hand, in the Biała Podlaska Commune, there was a collective wastewater treatment plant with the smallest capacity $-30 \mathrm{~m}^{3} / \mathrm{d}$.

The surveys conducted in 2016 in the districts adjacent to the Bialski District show that 12 collective biological wastewater treatment plants with a capacity of more than $5 \mathrm{~m}^{3} / \mathrm{d}$ were operating in the Parczew District [Micek et al. 2018] and on the territory of the Radzyn District there were 8 collective biological wastewater treatment plants [Bogusz et al. 2020].

According to the National Urban Wastewater Treatment Programme (KPOŚK), the use of a collective wastewater system and a wastewater treatment plant is justified when there are no less than 120 inhabitants per one kilometer of the wastewater network (excluding house drains).

Table 4. Collective wastewater treatment plants in the Bialski District

\begin{tabular}{|l|c|c|}
\hline \multicolumn{1}{|c|}{$\begin{array}{c}\text { Name of the } \\
\text { commune }\end{array}$} & $\begin{array}{c}\text { Name of the } \\
\text { wastewater } \\
\text { treatment plant }\end{array}$ & $\begin{array}{c}\text { Capacity of the } \\
\text { treatment plant } \\
{\left[\mathrm{m}^{3} / \mathrm{d}\right]}\end{array}$ \\
\hline Biała Podlaska & Woroniec & 30 \\
\hline Janów Podlaski & Janów Podlaski & 400 \\
\hline \multirow{2}{*}{ Kodeń } & Kodeń & 600 \\
\cline { 2 - 3 } & Kostomłoty & 70 \\
\hline Konstantynów & Konstantynów & 320 \\
\hline Leśna Podlaska & Leśna Podlaska & 400 \\
\hline Łomazy & Łomazy & 250 \\
\hline Międzyrzec Podlaski & Międzyrzec Podlaski & 2000 \\
\hline (urban) & Dąbrowica Mała & 35 \\
\cline { 2 - 4 } Piszcząc & Piszcząc & 360 \\
\cline { 2 - 4 } & Trojanów & 150 \\
\hline Rokitno & Cieleśnica & 90 \\
\hline Sławatycze & Sławatycze & 300 \\
\hline Terespol & Koroszczyn & 500 \\
\hline Terespol (urban) & Terespol Wschód & 600 \\
\hline Tuczna & Tuczna & 120 \\
\hline \multirow{2}{*}{ Wisznice } & Wisznice Kolonia & 380 \\
\hline \multirow{2}{*}{ Zalesie } & Marylin & 500 \\
\hline \multirow{2}{*}{ Totesie } & 100 \\
\cline { 2 - 4 } & Kijowiec & 505 \\
\hline
\end{tabular}

The households which are not connected to the sewerage network discharge wastewater mainly to septic tanks, as their construction does not involve high financial outlays. However, many of them do not fulfill their role, because the requirement of keeping tightness is not maintained during construction, which results in the migration of pollutants to the ground and groundwater pollution. This is due to a low ecological awareness of the inhabitants of Bialski District and limited financial resources. The results of the survey from 2016 did not allow to determine the exact number of septic tanks existing in the Bialski District, because 13 communes did not provide any information about them. The data from 6 communes indicate the existence of 1662 such facilities, only 528 of which (almost $32 \%$ ) signed an agreement with a company accountable for treating pollutants. This may indicate that a significant part of wastewater was not received to collective wastewater treatment plants, but was poured into fields, which might lead to the degradation of the groundwater quality.

In the rural areas with scattered housing, it is reasonable to invest in the construction of household wastewater treatment plants. Their number is steadily increasing every year because they are much cheaper to operate than septic tanks [Karolinczak et al. 2015]. The following technological systems can be used in household wastewater treatment plants: septic tank with drainage system, septic tank with ground filter (sand), container wastewater treatment plants with active sludge, container wastewater treatment plants with biological bed and constructed wetlands [Pawełek, Bugajski 2017].

The conducted survey shows that in 2016 there were 4437 household wastewater treatment plants of various types in the communes of the Bialski District (Table 5). Figure 4 shows the number of household wastewater treatment plants in individual communes in the Bialski District.

Table 5. Types of household wastewater treatment plants in the Bialski District

\begin{tabular}{|l|c|}
\hline \multicolumn{1}{|c|}{$\begin{array}{c}\text { Type of a wastewater } \\
\text { treatment plant }\end{array}$} & $\begin{array}{c}\text { Number of facilities } \\
\text { in the district }\end{array}$ \\
\hline Drainage systems & 3559 \\
\hline Active sludge & 660 \\
\hline Constructed wetlands & 171 \\
\hline Hybrid systems & 40 \\
\hline Biological beds & 7 \\
\hline TOTAL & $\mathbf{4 4 3 7}$ \\
\hline
\end{tabular}




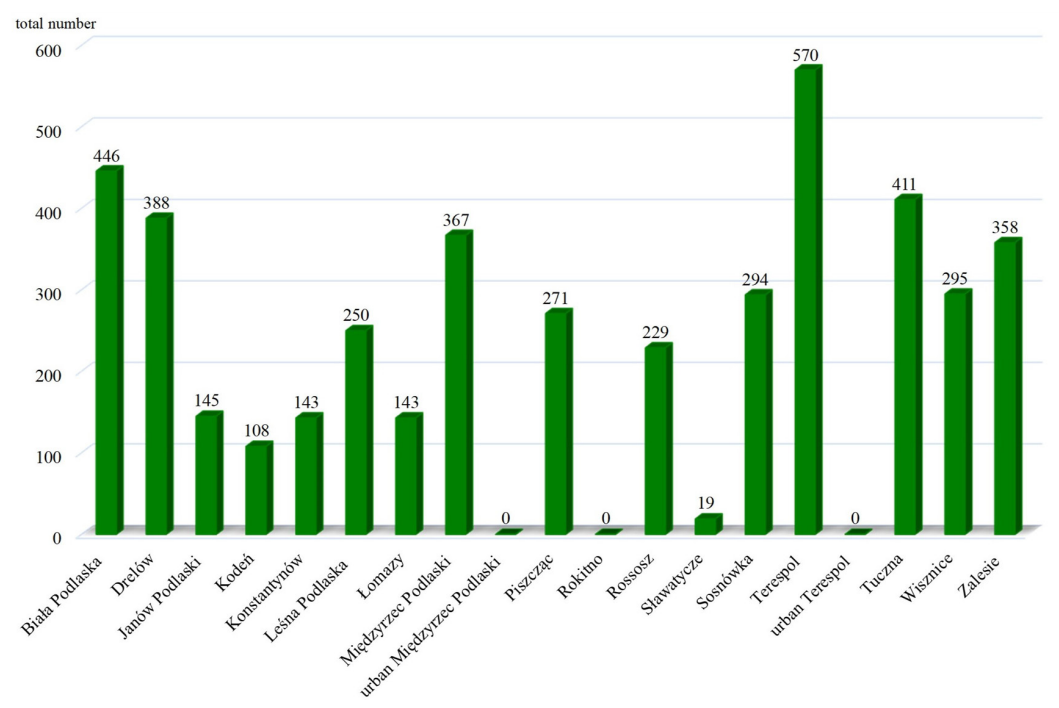

Fig. 4. The number of household wastewater treatment plants in the communes of the Bialski District in 2016

The data presented in Table 5 show that the treatment plants based on a technological system with a septic tank and drainage system constituted $80.2 \%$ of all the household facilities in the commune. They are easily accessible and affordable, which is why they are willingly bought and installed by the inhabitants of this region. However, they do not offer the possibility to control the quality of the treated wastewater, as their operation is based on discharging the mechanically treated wastewater into the ground. Such a practice may cause the groundwater quality degradation [Jucherski, Walczowski 2001; Jóźwiakowski et al. 2014; Pawełek, Bugajski 2017]. Therefore, it is necessary to promote and implement such solutions which limit the possibility of environmental pollution, ensure high effects of wastewater pollutants removal and will be characterized by high reliability of operation. Such facilities include conventional wastewater treatment methods and constructed wetlands, which are recommended by many authors [Dębska et al. 2015; Gajewska et al. 2015; Jóźwiakowski et al. 2015; Gizinska et al. 2016; Jóźwiakowski et al. 2017; Jóźwiakowski et al. 2018; Jucherski et al. 2017].

In order to solve the existing problems connected with water and wastewater management occurring in the communes within Bialski District, it is necessary to further develop not only collective water supply and sewerage systems but also municipal wastewater treatment plants, as well as to equip the areas characterized by dispersed housing with highly efficient household wastewater treatment plants, such as constructed wetlands.

\section{CONCLUSIONS}

1. The current state of the sanitary infrastructure in the communes, within the area of the Bialski District, is not satisfactory and may have a significant impact on the pollution of the natural environment.

2. A very large disproportion between the state of the water supply system and wastewater system was observed in the analyzed communes. In 2016, the length of the sewerage system constituted only $26 \%$ of the length of the water supply network.

3 . In 2016 , the water supply system was used by $79.2 \%$ of the district inhabitants, on average. In four communes the percentage of the population using the water supply system did not exceed $60 \%$, in the remaining communes it was between 80 and $100 \%$.

4. It was found that $39.4 \%$ of the population used collective wastewater disposal systems in the communes of the Bialski District, whereas three communes did not have any sewerage systems.

5. In 2016 , there were 20 collective mechanical-biological wastewater treatment plants with a capacity of more than $5 \mathrm{~m}^{3} / \mathrm{d}$ in the Bialski District communes. Their total capacity was over $6800 \mathrm{~m}^{3} / \mathrm{d}$.

6. In 2016, more than 4400 household wastewater treatment plants operated in the Bialski District, over $80 \%$ of which were the facilities with drainage systems.

7. In order to protect the natural environment in the Bialski District, it is necessary to undertake investment activities that will contribute to the improvement of the current state of the sanitary infrastructure. Particular attention should 
be paid to the need to build and modernize the water supply networks and collective systems for wastewater collection and treatment.

\section{REFERENCES}

1. AKPOŚK. 2017. Update of the National Municipal Wastewater Treatment Programme, Państwowe Gospodarstwo Wodne Wody Polskie (in Polish).

2. Bogusz M., Marzec M., Malik A., Jóźwiakowski K. 2020. The state and the needs of the development of water supply and sewerage infrastructure in the Radzyń District. Journal of Ecological Engineering, DOI: 10.12911/22998993/118282 (in print).

3. CSO. 2019. Environmental Protection. Central Statistical Office, Warsaw (in Polish).

4. CSO. 2017. Lublin Voivodeship. Subregions. Districts. Communes. Warsaw (in Polish).

5. CSO. 2016. Local Data Bank. Warsaw (in Polish).

6. Dębska A., Jóźwiakowski K., Gizińska-Górna M., Pytka A., Marzec M., Sosnowska B., Pieńko A. 2015. The efficiency of pollution removal from domestic wastewater in constructed wetland systems with vertical flow with Common reed and Glyceria maxima. Journal of Ecological Engineering, 16(5), 110-118.

7. Gajewska M., Jóźwiakowski K., Ghrabi A., Masi F. 2015. Impact of influent wastewater quality on nitrogen removal rates in multistage treatment wetlands. Environ. Sci. Pollut. Res. 22, 12840-1284.

8. Gizińska-Górna M., Czekała W., Jóźwiakowski K., Lewicki A., Dach J., Marzec M., Pytka A., Janczak D., Kowalczyk-Juśko A., Listosz A. 2016. The possibility of using plants from hybrid constructed wetland wastewater treatment plants for energy purposes. Ecological Engineering, 95, 534-541.

9. Bialski DistrictHeidrich Z., Stańko M. 2008. Directions of solutions of wastewater treatment plants for rural settlement units. Infrastructure and Ecology of Rural Areas, 5, 169-177 (in Polish).

10. http1. access 22.01.2020. https://commons.wikimedia.org/w/index.php?curid=1939606

11.http2. commune information portal, access 22.01.2020 (in Polish). https://www.wisznice.pl/

12. Jóźwiakowski K., Bugajski P., Kurek K., de Carvalho M.F, Almeida M.A., Siwiec T., Borowski G., Czekała W., Dach J., Gajewska M. 2018. The efficiency and technological reliability of biogenic compounds removal during long-term operation of a one-stage subsurface horizontal flow constructed wetland. Separation and Purification Technology 202, 216-226.

13. Jóźwiakowski K., Bugajski P., Mucha Z., Wójcik W., Jucherski A., Natawny M. Siwiec T., Mazur A., Obroślak R., Gajewska M. 2017. Reliability of pollutions removal processes during long-term operation of one-stage constructed wetland with horizontal flow. Separation and Purification Technology 187, 60-66.

14. Jóźwiakowski K., Mucha Z., Generowicz A., Baran S., Bielińska J., Wójcik W. 2015. The use of multicriteria analysis for selection of technology for a household WWTP compatible with sustainable development. Archives of Environmental Protection, 41(3), 76-82.

15. Jóźwiakowski K., Steszuk A., Pieńko A., Marzec M., Pytka A., Gizińska M., Sosnowska B., Ozonek J. 2014. Evaluation of the impact of wastewater treatment plants with drainage system on the quality of groundwater in dug and deep wells. Inżynieria Ekologiczna, 39, 74-84 (in Polish).

16. Jucherski A, Nastawny M., Walczowski A., Jóźwiakowski K., Gajewska M. 2017. Assessment of the technological reliability of a hybrid constructed wetland for wastewater treatment in a mountain ecotourist farm in Poland. Water Sci. Technol. 75(11), 2649-2658.

17. Jucherski A, Walczowski A. 2001. Drainage systems. Cleaning or discharging untreated wastewater into the soil. Wiadomości Melioracyjne i Łąkarskie 3(390), 131-132 (in Polish).

18. Karolinczak B., Miłaszewski R., Sztuk A. 2015. Cost-effectiveness analysis of different technological variants of single-house wastewater treatment plants. Archives of Environmental Protection, 17, 726-746 (in Polish).

19. KPOŚK. 2017. National Municipal Wastewater Treatment Programme, Państwowe Gospodarstwo Wodne Wody Polskie (in Polish).

20. Local Government Portal 2017. Water Supply and Sewerage Management in Poland (in Polish). https://www.portalsamorzadowy.pl/gospodarka-komunalna/gospodarka-wodociagowa-ikanalizacyjna-w-polsce-w-2017-roku,110025.html

21. Micek A., Marzec M., Jóźwiakowska K., Pochwatka P. 2018. The condition of sanitary infrastructure in the Parczew District and the need for its development. Journal of Ecological Engineering, 19(5), 107-115.

22. Pawełek J., Bugajski P. 2017. The development of household wastewater treatment plants in Poland - advantages and disadvantages. Acta Scientiarum Polonorum, Formatio Circumiectus, 16(2), 3-14 (in Polish).

23. Statistical Office in Lublin. 2019. Statistical Vademecum of the Local Government, Bialski District - A statistical portrait of the territory, Lublin (in Polish), https://lublin.stat.gov.pl/ statystyczne-vademecum-samorzadowca/

24. Statistical Office in Lublin. 2017. Water supply and wastewater management in Lublin Voivodeship in 2016. Lublin (in Polish).

25. The District Office in Biala Podlaska. 2020. Economy of Bialski District, access 22.01.2020 (in Polish), http://www.powiatbialski.eu/?page_id=112. 